\title{
Can ACE Inhibitors and Angiotensin Receptor Blockers Be Detrimental in CKD Patients?
}

\author{
Macaulay A.C. Onuigbo \\ College of Medicine, Mayo Health System Practice-Based Research Network, Mayo Clinic, Rochester, Minn., and \\ Department of Nephrology, Midelfort Clinic, Mayo Health System, Eau Claire, Wisc., USA
}

\section{Key Words}

Acute kidney injury - Angiotensin-converting enzyme inhibitors · Angiotensin receptor blockers · Chronic kidney disease $\cdot$ End-stage renal disease $\cdot$ Late-onset renal failure from angiotensin blockade $\cdot$ Renoprotection .

Renoprevention - Syndrome of rapid-onset end-stage renal disease

\begin{abstract}
Current epidemiological data from the USA, Europe, Asia and the Indian subcontinent, Africa, the Far East, South America, the Middle East and Eastern Europe all point to the increasing incidence of renal failure encompassing acute kidney injury (AKI), chronic kidney disease (CKD) and endstage renal disease (ESRD). While the explanations for these worldwide epidemics remain speculative, it must be acknowledged that these increases in AKI, CKD and ESRD, happening worldwide, have occurred despite the universal application of strategies of renoprotection over the last 2 decades, more especially the widespread use of angiotensin-converting enzyme inhibitors (ACEls) and angiotensin receptor blockers (ARBs). We note that many of the published large renin-angiotensin-aldosterone system (RAAS) block-
\end{abstract}

ade randomized controlled trials, upon which current evidence-based practice for the increasing use of ACEls and ARBs for renoprotection derived from, have strong deficiencies that have been highlighted over the years. From reports in the literature, there is an increasing association of exacerbations of renal failure with ACEls and ARBs, more so in the older hypertensive patient, $>65$ years old. The biological plausibility for ACEI and ARB to protect the kidneys against a background of potential multiple pathogenetic pathways to account for CKD progression appears to be not very defensible. We reviewed the literature along these lines and submit that ACEls and ARBs often cause unrecognized significant worsening renal failure in CKD patients, sometimes irreversible, and that more caution is required regarding their use, especially in the older hypertensive patients, with likely ischemic hypertensive nephropathy. Given the increasing association of concomitant RAAS blockade with worsening renal failure following exposure to iodinated contrast, during acute illness, in the perioperative period and following lower bowel preparations prior to colonoscopy, we submit that, preferably, ACEls and ARBs be withheld for 2-4 days prior to or during these clinical scenarios. This represents the concept of renoprevention.

Copyright $\odot 2011$ S. Karger AG, Basel

\section{KARGER}

Fax +4161306 1234 E-Mail karger@karger.ch www.karger.com
(C) 2011 S. Karger AG, Basel

$1660-2110 / 11 / 1184-0407 \$ 38.00 / 0$

Accessible online at:

www.karger.com/nec
Macaulay Onuigbo, MD, MSc, FWACP, FASN

Department of Nephrology, Midelfort Clinic

Mayo Health System, 1221 Whipple Street

Eau Claire, WI 54702 (USA)

Tel. +1 715838 3891, E-Mail onuigbo.macaulay@mayo.edu 


\section{Introduction - The Renal Failure Epidemic around the World Continues}

Current epidemiological data from the USA, Europe, Asia and the Indian subcontinent, Africa, the Far East, South America, the Middle East and Eastern Europe all point to the increasing incidence of renal failure encompassing acute kidney injury (AKI), chronic kidney disease (CKD) and end-stage renal disease (ESRD) [1-18]. According to ESRD statistics released by the United Sates Renal Data System in October 2010, the prevalent ESRD population in the USA reached an all-time high of 547,982 as of December ending 2008 [19]. This represented a 1.2\% jump from 2007, compared to a $0.85 \%$ increase from 2006 to 2007 [19]. The argument by some authorities that the prevalence of ESRD in the USA is rising but only due to increased survival of patients with ESRD is not valid since the incident ESRD population for 2007 was 108,335 compared to a higher incidence value of 112,476 in 2008 [19]. Besides, in the USA, between 1996 and 2003, the incidence of nondialysis requiring community-based AKI increased from $322.7 / 100,000$ to $522.4 / 100,000$ personyears [20]. Equally, the incidence of dialysis-requiring AKI increased from $19.5 / 100,000$ to $29.5 / 100,000$ personyears [20]. Hospital incidence for AKI per 10,000 population in the USA increased from 1.8 in 1980 to a shocking 36.5 in 2005 [21]. Simultaneously, in 2008, a US Centers for Disease Control and Prevention report showed an acceleration of CKD prevalence up to $16.5 \%$ among the US population aged $\geq 20$ years in the period 1999-2004, representing a $15.9 \%$ increase in CKD prevalence when compared to the 1988-1994 period [22]. Across Africa, several recent reports have described ESRD rates increasing by $75 \%$ between 2000 and 2004 [23], CKD accounting for nearly $10 \%$ of hospital admissions $[24,25]$, renal outpatient visits representing nearly $25 \%$ of all medical outpatient attendance and deaths from renal disease accounting for over $20 \%$ of all medical deaths [15]. Furthermore, from Eastern Europe, the same picture of an increasing ESRD population continues to unfold $[9,26]$. In Romania, Eastern Europe, national statistics from 2003 showed that ESRD and renal replacement therapy (RRT) incidence had increased to 128 per million population with a prevalence of 250 per million population, and these numbers represented $500 \%$ and $600 \%$ increases, respectively, compared to figures from 1996 [26]. A previous report from the same group had revealed that in 1995, only one third of the patients needing RRT could be treated then in Romania [9]. With an increase in the number of available dialysis units in Romania, mostly continuous ambu- latory peritoneal dialysis units, the RRT coverage for patients with ESRD in the Eastern European country had improved very dramatically, when compared to the mid 1990s [26]. Additionally, recent ESRD Registry data from the UK show that there were 45,484 patients receiving RRT by December 31, 2007, and this represented an annual growth rate of $5 \%$ for patients receiving RRT, according to 2009 published data [18].

While the explanations for these worldwide epidemics remain speculative, it must be acknowledged that these increases in AKI, CKD and ESRD, happening worldwide, have occurred despite the universal application of strategies of renoprotection over the last 2 decades, especially the widespread use of angiotensin-converting enzyme (ACE) inhibitors (ACEIs) and angiotensin receptor blockers (ARBs) [27-36].

\section{Mechanisms of CKD Progression Still Remain Uncertain}

The mechanisms underlying the development of albuminuria in diabetic nephropathy remain controversial and continue to be vigorously debated $[37,38]$. The exact anatomical site of the damage to the kidneys that relates to the poor renal outcomes in diabetic nephropathy is also questionable [37, 38]. As recently as 2009, new published experimental evidence suggests that, in fact, tubular dysfunction constituted the primary factor in the causation of early albuminuria from diabetic nephropathy as against a glomerular origin, the latter presumption being the more traditional consensus $[37,38]$. Furthermore, the culprit pathogenetic molecule responsible for the initiation and propagation diabetic nephropathy remains unproven and uncertain [39-53]. Several independent and often conflicting lines of evidence from both human and experimental studies point to a variety of different pathogenetic mechanisms including oxidative stress, underlying genetic predispositions such as the nonmuscle myosin heavy-chain 9 gene on chromosome 22 or variants at chromosome 6q24-27 among African Americans [3942], the production of advanced glycosylation end-products and the interaction of these end-products on the multiligand receptor of the immunoglobulin superfamily receptor for advanced glycation end-products [43, 44], a role for intrarenal angiotensin II and/or renin production [45], pathogenetic roles for inflammation [46], lipid toxicity $[47,49]$, podocyte injury and apoptosis [50, 51], and chemokine/growth factor release causing renal injury $[52,53]$. 
Moreover, the prevailing consensus among nephrologists and internists is the commonly accepted archetype of a predictable and orchestrated progression of kidney involvement in diabetic nephropathy over the years, starting with a period of normoalbuminuria, then the inception of microalbuminuria with hyperfiltration, then the advancement to macroalbuminuria, then overt proteinuria, followed by a doubling of serum creatinine, and ultimately the subsequent progression to ESRD and need for RRT [54]. This model is significantly flawed, is not based on any established evidence and remains unproven $[55,56]$. The proportion of CKD patients with diabetic nephropathy who progress so predictably and orderly along this predicted model remains unknown and unclear [56]. Indeed, Tsalamandris et al. [57] had followed 40 diabetic patients and demonstrated a complete disassociation between albumin excretion rates (AERs) and 24-hour creatinine glomerular filtration rate (GFR) values with time. During a 7-year follow-up, a progressive increase in AER was observed in 15 (38\%) patients without any decline in GFR, a progressive increase in AER concurrent with decreasing GFR in 13 (33\%) patients, consistent with the archetypal pattern of diabetic nephropathy, and another group of 12 (30\%) patients demonstrated decreasing GFR without any significant increase in AER [57]. Despite these drawbacks and uncertainties, much of the evidence base supporting the use of renin-angiotensin-aldosterone system (RAAS) blockade for renoprotection derive from claims of antiproteinuric effects of ACEIs and ARBs.

Furthermore, there is significant uncertainty about the natural history of $\mathrm{CKD}$, in general as current literature on ESRD rates and mortality rates in CKD remains conflicting, nonuniform and even controversial [58-60]. Different reports have demonstrated widely dissimilar and varying ESRD and mortality rates among CKD patients [58-60]. We cannot agree more with Bansal and Hsu [61], who in a recent review of the presentation and prognosis of CKD had emphasized on the heterogeneity of the CKD population and had concluded that CKD patient prognostication and management must be individualized [62].

From the foregoing, it is only fair to conclude that the pathogenetic mechanisms of the chronic nephropathies, CKD in general, hypertensive, diabetic and nondiabetic alike, remain mostly speculative and conjectural at this time, and therefore the hope or claims that any one specific treatment method targeting only one pathogenetic mechanism could successfully retard or reverse CKD progression can only, as of now, be tentative and provi- sional, but not proven. Also the natural history of CKD remains unclear, and a no-one-size-fits-all approach must be adopted for all CKD patients.

\section{A Brief Critique of the Evidence Base for Renoprotection with RAAS Blockade}

Many of the published large RAAS blockade randomized controlled trials (RCTs), upon which current evidence-based practice for the increasing use of the ACEIs and ARBs for renoprotection derived from, have strong deficiencies that have been highlighted over the years [55, 56, 63-80]. These RCTs have several design flaws, and questions abound regarding the general applicability of the trial findings from these RCTs to the general CKD population, more so the older ( $>65$-year-old) CKD patients $[55,56,63-80]$. The several limitations and concerns raised regarding the veracity of the claims of these RCTs as well as doubts regarding the general applicability of the recommendations of the large RAAS blockade RCTs to especially the older CKD patient population include the following:

- Several RAAS blockade RCTs were relatively shortterm studies with some reported studies often as short as $8-12$ weeks [81].

- The RAAS blockade RCTs often enrolled younger patients usually with well-preserved baseline renal function; notably, as an exception, we note here that the RENAAL and IDNT trials recruited patients with fairly advanced CKD with baseline serum creatinine of 1.9 and $1.7 \mathrm{mg} / \mathrm{dl}$, respectively [64, 67].

- Most of the RCTs involved a middle-aged patient population with relatively few comorbid conditions, previous known exposure to ACEIs or ARBs, proven tolerance to maximum doses of these agents, and these were patients with well-established drug adherence.

- Claims of renoprotection beyond blood pressure (BP) lowering have not been proven and are very doubtful as indeed a post hoc substudy analysis of the HOPE trial cohort had demonstrated that patients in the ramipiril arm actually achieved significantly lower 24-hour BP levels compared to the placebo arm [82]. Also in other trials where BP-independent effects were claimed such as the RENAAL and IDNT trials, the treatment arms actually showed mean arterial BP values lower than placebo arms of as much as $3 \mathrm{~mm}$ $\mathrm{Hg}$ or more [64, 67]. Similarly, the patients in the combination arm of the ONTARGET trial demonstrated lower BP levels $(2.4 / 1.4 \mathrm{~mm} \mathrm{Hg})$ throughout 
the study period compared to the monotherapy arm [74].

- Methodological flaws in some of the RCTs comprise the use of often unrelated composite end points including both surrogate and nonsurrogate markers raising doubts about the internal validity of the statistical analysis of such data with a very high likelihood of suffering from the phenomena of ecological fallacy and Simpson's paradox [56, 83-85]. Furthermore, there sometimes is excessive emphasis placed on the magnitudes of reduction of levels of proteinuria in the patients studied as definitive and proven renal end points, even though this premise of using proteinuria reduction as a therapeutic end point has never been validated in any studies $[56,77,86]$.

- Many of the RCTs contain statistical inconsistencies and apparent aberrations like the observation of substantial risk reductions in the doubling of serum creatinine and ESRD at the same time as a higher death rate in the losartan group versus placebo in the RENAAL study $[64,77]$.

- In many of the RAAS blockade RCTs, trial drug(s) discontinuation rates have been unacceptably high. In the RENAAL trial, the trial drug was discontinued in $46.5 \%$ of patients on losartan versus a drug discontinuation rate of $53.5 \%$ in the placebo arm $[64,77]$. The implications of these very high drug discontinuation rates in the RCT trials and the impact of these high study drug discontinuation rates on reported study outcomes and on statistical analysis can only remain hypothetical, and very open to strong debate and controversy among experts in the field.

- The fact that despite the claims of many large RAAS blockade RCTs of a relatively high exclusion criterion for serum creatinine being set at $>2.5 \mathrm{mg} / \mathrm{dl}$, and the observation that the majority of these trials only ended up recruiting and studying patients with mean serum creatinine usually in the more normal 1.3-1.5 $\mathrm{mg} / \mathrm{dl}$ range $[55,56,72,74,77]$, raises some serious questions about the role of a selection bias for patients with preserved baseline renal function $[55,56,77]$. As a result, the extrapolation of many of the RCTs to the older CKD population is even more in doubt $[55,56$, $72,77]$.

- As a final point, the RAAS blockade RCTs generally lacked strict systematic assessment methods, and were very deficient in the reporting of adverse events, thus raising concerns about safety issues including the underreporting of a potential nephrotoxicity of these agents [79].

\section{Biologic Plausibility for Renoprotection with RAAS Blockade Questioned - The Absence of Proof of a Dose-Response Relationship between Increasing RAAS Blockade and the Achievement of Incremental Renal Benefits}

As a result of the evidence recorded above, depicting the heterogeneity of the CKD population, the multiple pathways that potentially influence the initiation of, and the propagation of the chronic nephropathies, hypertensive, diabetic and nondiabetic, it is puzzling for the supposition that any one agent could then become the magic bullet in this area of medicine as some authorities would like to suggest the ACEIs and ARBs to be $[55,56]$. Moreover, claims of BP-independent renoprotection by ACEIs and ARBs cannot be defensible following the report from Svensson et al. [82] cited earlier.

We must also note here that the rush to achieve total RAAS blockade in our patients is in antithesis to common sense physiology since the molecule angiotensin II does in fact have considerable physiological roles in the kidney and elsewhere in the body, both in health and in disease [87-89]. There is ample incontrovertible evidence for critically important physiological roles for angiotensin II, as an endocrine agent, in the orchestration of wellmodulated and controlled renal glomerular and tubular transport systems [87]. Also, experimental evidence suggests that angiotensin II, acting through several genetic pathways, has crucial physiological roles in central tissue repair processes in the kidney, especially following renal injury $[88,89]$. We would therefore argue that the concept of aggressive total RAAS blockade should not be pushed too far, beyond reason $[55,56]$.

Finally, if one were to assume that, indeed, all diabetic nephropathies were one homogenous entity and that all the pathogenetic derangements at play in the initiation and propagation of diabetic nephropathy were all secondary to the adverse consequences of angiotensin II overactivity, it stands to reason to expect a dose-response relationship between increasing RAAS blockade and improved effects of renoprotection in these patients. However, to the contrary, there is accruing evidence to date, in the literature, that posits that total RAAS blockade with combination ACEI + ARB or the use of supratherapeutic doses of ARBs have only resulted in worse renal outcomes, both in the short term, as shown in the report by Rossing et al. [90], and in the long term, as clearly evident in the results of the ONTARGET studies of over 25,000 patients $[91,92]$. 
Table 1. Mortality versus ESRD rates in some RAAS RCTs showing statistical aberrations

\begin{tabular}{|c|c|c|c|c|c|c|c|c|}
\hline $\begin{array}{l}\text { Trial } \\
\text { (publica- } \\
\text { tion, year) }\end{array}$ & $\begin{array}{l}\text { Study } \\
\text { size, } \mathrm{n}\end{array}$ & $\begin{array}{l}\text { Mean } \\
\text { age } \\
\text { years }\end{array}$ & $\begin{array}{l}\text { Trial drug vs. } \\
\text { placebo/other }\end{array}$ & $\begin{array}{l}\text { Indication for trial } \\
\text { drug }\end{array}$ & $\begin{array}{l}\text { Follow- } \\
\text { up } \\
\text { months }\end{array}$ & $\begin{array}{l}\text { Baseline mean } \\
\text { serum creati- } \\
\text { nine, } \mathrm{mg} / \mathrm{dl}\end{array}$ & $\begin{array}{l}\text { ESRD/dialysis rate } \\
\text { trial drug vs. } \\
\text { placebo/other, } \%\end{array}$ & $\begin{array}{l}\text { All-cause mortality } \\
\text { trial drug vs. } \\
\text { placebo/other, \% }\end{array}$ \\
\hline $\begin{array}{l}\text { REIN } \\
(1999)\end{array}$ & 186 & 49.5 & $\begin{array}{l}\text { ramipril (99) } \\
\text { vs. placebo (87) }\end{array}$ & $\begin{array}{l}\text { renoprotection in } \\
\text { nondiabetic CKD }\end{array}$ & & 1.9 & $\begin{array}{l}9 \text { vs. } 20.7 \\
(p=0.04)\end{array}$ & $\begin{array}{l}1 \text { vs. } 0 \\
(p=0.94, \text { n.s. })\end{array}$ \\
\hline $\begin{array}{l}\text { IDNT } \\
(2001)\end{array}$ & 1,715 & 59 & $\begin{array}{l}\text { irbesartan (579) } \\
\text { vs. amlodipine (567) }\end{array}$ & $\begin{array}{l}\text { renoprotection in } \\
\text { type } 2 \text { diabetes mellitus }\end{array}$ & 31 & 1.7 & $\begin{array}{l}14.2 \text { vs. } 18.3 \\
(p=0.07, \text { n.s. })\end{array}$ & $\begin{array}{l}15 \text { vs. } 14.6 \\
(p=0.9, \text { n.s. })\end{array}$ \\
\hline $\begin{array}{l}\text { IDNT } \\
(2001)\end{array}$ & 1,715 & 59 & $\begin{array}{l}\text { irbesartan (579) } \\
\text { vs. placebo (569) }\end{array}$ & $\begin{array}{l}\text { renoprotection in } \\
\text { type } 2 \text { diabetes mellitus }\end{array}$ & 31 & 1.7 & $\begin{array}{l}14.2 \text { vs. } 17.8 \\
(p=0.1, \text { n.s. })\end{array}$ & $\begin{array}{l}15 \text { vs. } 16.3 \\
(p=0.6, \text { n.s. })\end{array}$ \\
\hline $\begin{array}{l}\text { RENAAL } \\
(2001)\end{array}$ & 1,513 & 60 & $\begin{array}{l}\text { losartan }(751) \\
\text { vs. placebo (762) }\end{array}$ & $\begin{array}{l}\text { renoprotection in } \\
\text { type } 2 \text { diabetes mellitus }\end{array}$ & 41 & 1.9 & $\begin{array}{l}19.6 \text { vs. } 25.5 \\
(p=0.007)\end{array}$ & $\begin{array}{l}21 \text { vs. } 20.3 \\
\text { ( } \mathrm{p}=0.8, \text { n.s.) }\end{array}$ \\
\hline
\end{tabular}

\section{Absence of Mortality Benefits in the RAAS Blockade Trials despite Purported Reduction in ESRD Rates}

Many RAAS blockade RCTs report statistically significant reductions of incident ESRD of up to $25 \%$ with follow-up [64, 65, 68, 69]. Crude annual mortality rates among US ESRD patients of $20 \%$ and over have been currently reported $[93,94]$. One would therefore surmise that any therapeutic intervention that successfully and consistently reduced incident ESRD rates by as much as $25 \%$, as claimed by the IDNT and RENAAL trials $[64,65,69]$, should begin to demonstrate definite mortality benefits after only a few years of follow-up [55, 77]. Quite the opposite, one interesting and glaring statistical inconsistency that was revealed during our review of the RAAS RCTs was that despite the reported ESRD reductions in the ARB trials, quite often, after years of follow-up, there failed to be demonstrated any mortality benefits with RAAS blockade $[55,64,65,69,77]$. These apparent statistical aberrations are shown in table 1 and demand further explanation.

\section{The Association of AKI with RAAS Blockade in General}

In the last 5 years, we have published several reports from our single-center experience describing sometimes reversible AKI in CKD patients associated with concurrent RAAS blockade [55, 56, 71-76, 95]. The clinical circumstances under which we described worsening renal failure associated with concurrent RAAS blockade include the absence of any identifiable so-called precipitating risk factor [72], in association with multiple varied risk factors such as infections, heart failure exacerbation, hypotension and dehydration [70,72], in association with renal artery stenosis [75, 76], in hospitalized patients [95], and in association with contrast-induced nephropathy $[73,96]$. What is more, recently, sustained increases in estimated GFR (eGFR) were demonstrated from 16.4 to $26.6 \mathrm{ml} / \mathrm{min} / 1.73$ $\mathrm{m}^{2}$ body surface area, in 52 patients, mean age 73 years, following the discontinuation of ACEIs and/or ARBS [97, 98]. Besides, previously in a Canadian study, Suissa et al. [78] had demonstrated in a population-based historical cohort analysis of 6,102 diabetic patients (mean age 66 years) an increased ratio of ESRD of 4.2 (95\% CI 2.0-9.0), after 3 years or longer of ACE inhibition. As well, the CHARM trials revealed a higher rate of doubling of serum creatinine in $82(6 \%)$ candesartan-treated versus $47(4 \%)$ placebo-treated patients $(\mathrm{p}=0.002)[99,100]$. Additionally, the ALLHAT study demonstrated that among the diabetics studied, more patients in the ACEI lisinopril group progressed to ESRD, when compared to the diuretic chlorthalidone group (25/1,563 vs. $26 / 2,755, \mathrm{p}=0.05$, RR $1.74,95 \%$ CI 1.00-3.01) [101, 102]. Furthermore, Jones et al. [8] in 2005, after a thorough analysis of the US ESRD population growth, concluded that there was an ESRD epidemic here in the USA, and that the pace of the US ESRD epidemic outpaced the growth of the diabetes mellitus epidemic. The authors had examined the time trends in the US ESRD population, the diabetes literature and had come to the conclusion that the recent US ESRD epidemic could be related to the increasing use of ACEIs and ARBs since the 1990s [8]. Finally, drug-induced AKI, including the use of ACEIs and ARBs, accounted for a rising proportion of AKI among patients in two Jordanian hospitals in a recent analysis from the Middle East [103]. These observations must be taken very seriously, and our previous call for 
more circumspection in the use of these agents cannot be overemphasized $[55,56,77]$. It must be acknowledged that the ONTARGET trial demonstrated increased AKI requiring dialysis in the combination arm ( 0.8 vs. $0.6 \%)$, but overall, there was no demonstrable change in the rate of CKD progression between the 3 treatment arms and no evidence for increased ESRD $[74,86]$. Finally, given the preponderance of diabetes among the hypertension population, with $100 \%$ of the RENAAL and IDNT patients being diabetics, $45 \%$ of the ALLHAT hypertensives and $38 \%$ of the ONTARGET patients were diabetics, whereas nearly $70 \%$ of the ONTARGET patients were hypertensives, it is clearly untenable to begin to try to distinguish between study effects among CKD patients, as to hypertensive CKD versus diabetic CKD [64, 67, 74, 86, 101].

\section{RAAS Blockade and AKI in Specific Clinical Syndromes}

\section{Exacerbation of Acute Renal Failure Caused by} Contrast-Induced Nephropathy

Several reports had demonstrated an association between concurrent use of ACEIs and ARBs and the exacerbation of contrast-induced nephropathy in CKD patients [73, 77, 96, 104-108]. However, a few reports propose the opposite view that simultaneously administered ACEIs offer improved kidney protection and limit the effects of contrast-induced nephropathy on the kidneys $[109,110]$. The evidence in the literature, on the balance, is very much in favor of worse renal outcomes of contrast-induced nephropathy with concurrent RAAS blockade [73, $77,96,104-108]$. According to a recent post hoc analysis from the Dialysis-versus-Diuresis trial involving 412 patients, the patients treated with RAAS blockade (ACEIs or ARB), before exposure to contrast developed significantly more contrast-induced nephropathy within $72 \mathrm{~h}$ [111]. Even after adjustment for confounding comorbidities, treatment with ACEI or ARB turned out to be an independent risk predictor for contrast-induced nephropathy (11.9 vs. $4.2 \%, \mathrm{p}=0.006)$ [111]. Multivariate analyses (logistic regression) identified RAAS blockade to be an independent predictor of contrast-induced nephropathy (OR 3.082, 95\% CI 1.234-7.698, $\mathrm{p}=0.016$ ) [111]. Correspondingly, Komenda et al. [108] demonstrated improved renal outcomes when ACEIs were temporarily withheld from patients, 2 days before undergoing coronary angiography, when compared to historical controls.

The RCT reported by Gupta et al. [109] that concluded that the ACEI captopril was in fact renoprotective admin- istered the first dose of the trial drug captopril $25 \mathrm{mg}$ t.i.d. versus placebo, for 3 days, starting just $1 \mathrm{~h}$ prior to coronary angiography. Clearly, it would seem that this approach would not have allowed enough ACEI effect to be experienced by the drug recipients before being exposed to the contrast, and therefore arguably both placebo and captopril recipients may not have been different, after all. Other flaws and limitations with this study include the small study size and the fact that the one therapy that is known to influence the incidence of contrast-induced nephropathy which is periprocedural intravenous fluid hydration therapy, was not standardized and the different physicians in the study used whatever intravenous fluid hydration therapy they wanted for the study patients [109]. Our conclusion from a critical statistical review of the study is that the findings by Gupta et al. could easily be explained by inadequate randomization and by chance.

Another report by Rosenstock et al. [112] also suggested that the withholding of ACEIs and ARBs before contrast exposure did not alter renal outcomes. One major limitation of this study was the fact that the ACEIs or ARBs were withheld only $24 \mathrm{~h}$ prior to coronary angiography [112]. In patients with significant CKD, the knowledge of pharmacokinetics would argue that $24 \mathrm{~h}$ was not an adequate time for the effect of concurrent RAAS blockade to disappear following the drug discontinuation and before contrast administration [112]. We submit that this could have explained the failure of this study to demonstrate any renal benefits associated with the withholding of ACEI or ARB before contrast exposure, compared to patients who continued to take the ACEI or ARB throughout the study $[113,114]$. On this same basis, we would argue that the Canadian study by Komenda et al. [108] where the ACEI or ARB was stopped for a longer time interval before coronary angiography was then able to demonstrate improved renal outcomes when compared to historical controls in whom concurrent ACEI/ ARB therapy was continued uninterrupted through coronary angiography $[113,114]$.

\section{Exacerbation of Acute Renal Failure in the \\ Perioperative Period}

A recent literature review revealed an increasing number of reports that have continued to implicate the concurrent use of ACEIs and/or ARBs in the causation and aggravation of AKI on CKD patients following certain specific common procedures [115-122]. These procedures include postoperative states such as following gastric bypass surgery [115], after cardiac surgery [118] and following the use of oral phosphate sodium preparations 
Table 2. Chronological list of publications associating AKI with concurrent RAAS blockade in specific clinical scenarios

\begin{tabular}{|c|c|c|c|c|c|}
\hline Authors & Journal/year & Study type & $\begin{array}{l}\text { Study } \\
\text { size, } \mathrm{n}\end{array}$ & Clinical scenario & $\begin{array}{l}\text { Implicated } \\
\text { ACEI/ARB }\end{array}$ \\
\hline Onuigbo [96] & Mayo Clin Proc, 2008 & $\begin{array}{l}\text { retrospective case-matched } \\
\text { cohort study }\end{array}$ & 809 & contrast-induced nephropathy & ACEI/ARB \\
\hline $\begin{array}{l}\text { Al-Azzam } \\
\text { et al. [103] }\end{array}$ & Ren Fail, 2008 & prospective cohort study & 111 & $\begin{array}{l}\text { acute renal failure in hospitalized Jordanian } \\
\text { patients }\end{array}$ & $\mathrm{ACEI} / \mathrm{RB}$ \\
\hline $\begin{array}{l}\text { Khurana } \\
\text { et al. [116] }\end{array}$ & Arch Intern Med, 2008 & retrospective study & 286 & $\begin{array}{l}\text { acute renal failure after oral phosphate } \\
\text { sodium for bowel preparation }\end{array}$ & ACEI/ARB \\
\hline Arora et al. [118] & Clin J Am Soc Nephrol, 2008 & retrospective cohort study & 1,386 & acute renal failure following cardiac surgery & ACEI/ARB \\
\hline $\begin{array}{l}\text { Onuigbo and } \\
\text { Onuigbo [72] }\end{array}$ & Int Urol Nephrol, 2008 & $\begin{array}{l}\text { prospective longitudinal } \\
\text { cohort study }\end{array}$ & 100 & general & ACEI/ARB \\
\hline $\begin{array}{l}\text { Onuigbo and } \\
\text { Onuigbo [73] }\end{array}$ & Ren Fail, 2008 & $\begin{array}{l}\text { prospective longitudinal } \\
\text { cohort study }\end{array}$ & 7 & $\begin{array}{l}\text { contrast-induced nephropathy in patients } \\
\text { concurrently on RAAS blockade }\end{array}$ & ACEI/ARB \\
\hline $\begin{array}{l}\text { Onuigbo and } \\
\text { Onuigbo [76] }\end{array}$ & Ren Fail, 2008 & $\begin{array}{l}\text { prospective longitudinal } \\
\text { cohort study }\end{array}$ & 5 & $\begin{array}{l}\text { acute renal failure in CKD in patients on } \\
\text { RAAS blockade without precipitating factors }\end{array}$ & ACEI/ARB \\
\hline $\begin{array}{l}\text { Onuigbo and } \\
\text { Onuigbo [75] }\end{array}$ & QJM, 2008 & $\begin{array}{l}\text { prospective longitudinal } \\
\text { cohort study }\end{array}$ & 26 & $\begin{array}{l}\text { acute renal failure in older CKD patients } \\
\text { with renal artery stenosis on RAAS blockade }\end{array}$ & ACEI/ARB \\
\hline $\begin{array}{l}\text { Onuigbo and } \\
\text { Onuigbo [76] }\end{array}$ & Ren Fail, 2008 & $\begin{array}{l}\text { prospective longitudinal } \\
\text { cohort study }\end{array}$ & 26 & $\begin{array}{l}\text { acute renal failure in older CKD patients } \\
\text { with renal artery stenosis on RAAS blockade }\end{array}$ & ACEI/ARB \\
\hline $\begin{array}{l}\text { Russmann } \\
\text { et al. [117] }\end{array}$ & Am J Gastroenterol, 2007 & retrospective cohort study & 2,352 & $\begin{array}{l}\text { acute renal failure after oral phosphate } \\
\text { sodium for bowel preparation }\end{array}$ & ACEI/ARB \\
\hline $\begin{array}{l}\text { Komenda } \\
\text { et al. [108] }\end{array}$ & Clin Exp Nephrol, 2007 & prospective case series & 31 & $\begin{array}{l}\text { contrast-induced nephropathy following } \\
\text { cardiac and peripheral angiography }\end{array}$ & ACEI/ARB \\
\hline Cirit et al. [107] & Nephron Clin Pract, 2006 & prospective controlled study & 230 & $\begin{array}{l}\text { contrast-induced nephropathy after } \\
\text { coronary angiography }\end{array}$ & ACEI \\
\hline Toprak et al. [106] & Anadolu Kardiyol Derg, 2003 & prospective controlled study & 80 & $\begin{array}{l}\text { contrast-induced nephropathy after } \\
\text { coronary angiography }\end{array}$ & captopril \\
\hline Louis et al. [104] & Ren Fail, 1996 & prospective cohort study & 214 & contrast-induced nephropathy & ACEI \\
\hline Thakar et al. [115] & Clin J Am Soc Nephrol, 2007 & $\begin{array}{l}\text { retrospective historical } \\
\text { cohort }\end{array}$ & 504 & $\begin{array}{l}\text { contrast-induced nephropathy in patients } \\
\text { following gastric bypass surgery }\end{array}$ & ACEI/ARB \\
\hline Kiski et al. [111] & Nephrol Dial Transplant, 2010 & $\begin{array}{l}\text { post hoc analysis of a } \\
\text { prospective controlled study }\end{array}$ & 412 & contrast-induced nephropathy & ACEI/ARB \\
\hline
\end{tabular}

for lower bowel preparations [116, 117, 120-122] (table 2). In a study of 504 patients who underwent gastric bypass surgery, preoperative use of ACEIs or ARBs (OR 2.06; 95\% CI 1.05-4.04) was associated with increased frequency of AKI [115]. Additionally, the perioperative use of ACEIs/ARBs has recently been demonstrated to be significantly associated with an increased risk for AKI after cardiac surgery in 2 tertiary medical centers in Buffalo, New York [118]. Based on these reports [115-122], and taken together with our single-center experiences, we have proposed that the prophylactic withholding of ACEIs and/or ARBs, during acute illness, in the perioperative period, and prior to contrast exposure, should become standard of care, to limit the impact of AKI in CKD patients $[55,56,77]$. We coined the term renoprevention to encompass these practices $[55,56]$.

Are ACE Inhibitors Detrimental in CKD Patients?

\section{RAAS Blockade, Acute Renal Failure and Renal Artery Stenosis}

The association of accelerated renal failure in CKD patients with renal artery stenosis (RAS), receiving ACEI or $\mathrm{ARB}$, has been acknowledged for a long time and is well reported in the literature [123-131]. However, these mostly retrospective reports, small case series and individual case reports concluded that there was the necessary requirement for additional precipitating risk factors to result in AKI in patients with RAS on concurrent RAAS blockade [75, 76, 123-131]. Some of these risk factors included the use of diuretics and the coadministration of nonsteroidal anti-inflammatory drugs, the so-called triple whammy effect $[132,133]$. These previous RAS studies had also implied the usual reversibility of the renal 
failure following drug withdrawal [123-131]. Furthermore, these earlier studies proposed the necessity for bilateral RAS lesions to be present in patients with dual kidneys, or the presence of unilateral RAS lesions in patients with single functioning kidneys, to allow for the precipitation of worsening renal failure by concomitant RAAS blockade [123-131]. Nevertheless, this current model of RAS and renal failure and RAAS blockade does not take into account the existence of microvascular renal arteriolar narrowing, not demonstrable on MRA or conventional angiography, and only evident on renal biopsy first described by Raine in 1990 [134]. Such microvascular renal arteriolar narrowing is still capable of stimulating a state of enhanced angiotensin II production from the renal juxtaglomerular apparatus in the same way as large RAS lesions do [72, 134]. We therefore had coined the term microvascular RAS to describe this previously unrecognized phenomenon that would then explain the precipitation of AKI in patients with normal-appearing renal arteries on conventional angiography while concurrently on an ACEI or an ARB [72]. This is the pathophysiological basis for the classic presentation of our recently described new syndrome of late-onset renal failure from angiotensin blockade [72].

\section{Critical Review of the Evidence Base for the Claims of a Relationship between the Levels of Proteinuria in CKD Patients and Efficacy of Renoprotection with RAAS Blockade}

The most quoted references for the claims that RAAS blockade has been demonstrated to be useful in CKD patients with proteinuria in excess of $1 \mathrm{~g}$ /day is a series of meta-analyses carried out by the ACE Inhibition in Progressive Renal Disease Study Group (AIPRD Study Group) [77, 135-137]. A critical review of these metaanalyses reveals very striking deficiencies [77].

In the last decade, 3 meta-analyses of patient level data carried out by the AIPRD Study Group on a total of 11 previously randomized controlled trials have consistently concluded that ACE inhibition in 1,860 pooled nondiabetic patients remained beneficial after adjustment for $\mathrm{BP}$ and urine protein excretion (relative risk 0.67, 95\% CI $0.53-0.84$ ) but that this benefit was not apparent in patients with baseline proteinuria of $<0.5 \mathrm{~g} /$ day [135-137]. A critical analysis of the AIPRD reports was made in our previous publication with the identification of several serious drawbacks in the meta-analyses including the following [77]:
- Two of the 11 analyzed studies were unpublished personal communications.

- The average age of the 1,860 pooled cohort was only 52 years.

- The mean duration of the studies was only 2.2 years.

- The cited studies generally utilized lower end doses of the various ACEIs.

- The methods and frequencies of measurement of proteinuria in the pooled 11 studies were disparate - 10 studies reported urine protein excretion as total 24hour urine protein excretion, whereas 1 study performed dipstick urinalysis on untimed urine samples with results noted simply as either 'positive' or 'negative'.

- There was no standardization of the protocol for BP measurements in the 11 pooled studies.

In spite of these limitations, the study authors were bold enough to make very significant scientific extrapolations with respect to the degree of proteinuria in relation to renal outcomes and response to ACE inhibition. Finally, all 1,860 patients were nondiabetics, and the extrapolation of such prognostications to diabetic CKD patients is essentially baseless [77]. Thus, claims of successful renoprotection with RAAS blockade in CKD patients with proteinuria $>1 \mathrm{~g}$ /day remains speculative and indeed unproven [77]. What is more, criticisms of the ALLHAT studies for not measuring proteinuria and the ONTARGET study for recruiting patients of whom only $4 \%$ had macroalbuminuria and $13 \%$ had microalbuminuria and the citation of these as major drawbacks to data interpretation and extrapolation from the ALLHAT and ONTARGET trials are therefore not warranted, after all.

\section{The Phenomenon of Syndrome of Rapid-Onset End-Stage Renal Disease and Implications for Renoprotection}

We again recently described the previously unrecognized syndrome of rapid-onset end-stage renal disease (SORO-ESRD) among CKD patients whereby, due to new medical and/or surgical events, the ensuing AKI leads to a precipitous fall in eGFR in previously stable CKD patients, leading to rapid and irreversible ESRD requiring RRT $[56,138]$. Larger multicenter studies are warranted to further study the impact of SORO-ESRD among ESRD populations around the world. We anticipate that the proposed new ASSESS-AKI study, the assessment, serial evaluation and subsequent sequelae of AKI study, that would enroll 1,100 adult CKD patients and 100 children 
undergoing cardiac surgery and prospectively follow CKD progression for 4 years, would further clarify the scope of SORO-ESRD among the US ESRD population [139]. If shown to be a significant contributor to the growth of the ESRD population, SORO-ESRD must then be taken into consideration in current discussions related to the concepts of renoprotection $[55,56,138]$. We would submit that this phenomenon of SORO-ESRD only adds more urgency to our previous calls for more renoprevention practices to reduce the incidence of AKI among CKD patients $[55,56,138]$. By renoprevention, we include the judicious avoidance of potential nephrotoxic agents such as the aminoglycosides to treat infections in CKD patients, the minimalization if not the total avoidance of the use of contrast in these patients together with periprocedural intravenous fluid hydration therapy as applicable, the prompt correction and treatment of hypovolemia and hypotensive states, the avoidance of hypotension during major surgical procedures, and, in our opinion most importantly, the temporary withholding for 2-4 days of ACEIs and ARBs, before major surgical operations, before contrast exposure and during any acute illnesses [55, 56, 77]. We hypothesize that these renoprevention measures would, from our experience, invariably reduce the incidence of AKI, lessen ESRD by reducing the incidence of SORO-ESRD events, reduce patient morbidity and mortality, and help save the increasingly scarce healthcare dollars both here in the USA and around the world $[55,56,77,95,138]$.

\section{Conclusion}

We conclude that physicians and healthcare providers ought to use ACEIs and/or ARBs with caution, especially in the older patients aged $>65$ years. We must bear in mind that these older patients were generally never studied in any of the RAAS RCTs. Our experience in our single center is very revealing where, of the $100 \mathrm{CKD}$ patients who showed often reversible AKI on CKD following the discontinuation of ACEIs and/or ARBs, $75 \%$ were aged over 65 years, $63 \%$ over 70 years, and $23 \%$ were indeed over 80 years old [72]. The experience from Sheffield, UK, where El Nahas and his group showed improved eGFR following the discontinuation of ACEI and/ or ARB in 52 CKD patients with a mean age of 73 years, only further consolidates these concerns $[97,98]$. These agents have to be used very sparingly in older patients and very close and indefinite monitoring of kidney function, at least every 2 months, is mandatory from our experi- ence, and not just for the first 30 days following drug initiation $[55,72,77]$. A repeat serum creatinine assessment is justified a week or so following any dose increase in these agents $[55,72,77]$. In some clinical settings, sometimes daily monitoring of serum creatinine is again justified as during acute illness, following contrast exposure and in the perioperative period. There should be no resistance to the thought of carrying out a trial discontinuation of the ACEI and/or ARB in any patient presenting with recent progressive loss of eGFR if this eGFR loss could not be explained otherwise [72]. No physician or healthcare provider hesitates to withdraw insulin from a diabetic patient following a severe life-threatening hypoglycemic event. Similarly, there is usually no hesitation to stop warfarin in a patient who is actively bleeding and could potentially die, irrespective of the indication(s) for the anticoagulation. In fact, we often have to correct the anticoagulation very quickly with the use of fresh frozen plasma infusions and the use of parenteral vitamin $\mathrm{K}$ injections. Correspondingly, no healthcare provider hesitates to stop an antihypertensive in a patient presenting with severe hypotension. We do not see any difference between these clinical scenarios and the necessity to discontinue the ACEI and/or the ARB in a CKD patient exhibiting unexplained progressive AKI on CKD which may terminate in irreversible ESRD and the need for RRT $[72,97,98,138]$. The 'Do no harm' Hippocrates oath must not be vilified, after all. CKD management must be individualized, as no one size fits all. If SORO-ESRD is shown to be prevalent among the ESRD population, this would call for even more major paradigm shifts in our current approach to the management of CKD in general, and ESRD in particular.

Finally, we would conclude by invoking the words of Santiago Ramón y Cajal (1852-1934), the Spanish histologist, physician, pathologist and Nobel laureate, whose pioneering investigations of the microscopic structure of the brain were so original and influential that he is considered by many to be the greatest neuroscientist of all time. Santiago Ramón y Cajal wrote, inter alia: 'In summary, there are no small problems. Problems that appear small are large problems that are not understood.' We would submit that late-onset renal failure from angiotensin blockade, SORO-ESRD and other yet to be recognized clinical syndromes related to the natural history of CKD are not small problems. They only appear small to those who do not understand them. 


\section{References}

1 Canadian Institute for Health Information: Treatment of End-Stage Organ Failure in Canada, 1999 to 2008 - CORR 2010 Annual Report. Ottawa, CIHI, 2010.

-2 Stewart JH, McCredie MR, Williams SM, Jager KJ, Trpeski L, McDonald SP, ESRD Incidence Study Group: Trends in incidence of treated end-stage renal disease, overall and by primary renal disease, in persons aged 20-64 years in Europe, Canada and the Asia-Pacific region, 1998-2002. Nephrology (Carlton) 2007;12:520-527.

-3 Imai E, Horio M, Iseki K, et al: Prevalence of chronic kidney disease (CKD) in the Japanese general population predicted by the MDRD equation modified by a Japanese coefficient. Clin Exp Nephrol 2007;11:156-163.

-4 Chiu YL, Chien KL, Lin SL, Chen YM, Tsai TJ, Wu KD: Outcomes of stage 3-5 chronic kidney disease before end-stage renal disease at a single center in Taiwan. Nephron Clin Pract 2008;109:c109-c118.

5 Afifi A, El Setouhy M, El Sharkawy M, et al: Diabetic nephropathy as a cause of end-stage renal disease in Egypt: a six-year study. East Mediterr Health J 2004;10:620-626.

6 Collins AJ, Foley RN, Herzog C, et al: United States Renal Data System 2008 annual data report. Am J Kidney Dis 2009;53(suppl):S1S374.

-7 Hsu CY, Vittinghoff E, Lin F, Shlipak MG: The incidence of end-stage renal disease is increasing faster than the prevalence of chronic renal insufficiency. Ann Intern Med 2004;141:95-101.

$\checkmark 8$ Jones CA, Krolewski AS, Rogus J, Xue JL, Collins A, Warram JH: Epidemic of endstage renal disease in people with diabetes in the United States population: do we know the cause? Kidney Int 2005;67:1684-1691.

\9 Ursea N, Mircescu G, Constantinovici N, Verzan C: Nephrology and renal replacement therapy in Romania. Nephrol Dial Transplant 1997;12:684-690.

- 10 Perico N, Plata R, Anabaya A, Codreanu I, Schieppati A, Ruggenenti P, Remuzzi G: Strategies for national health care systems in emerging countries: the case of screening and prevention of renal disease progression in Bolivia. Kidney Int Suppl 2005;97:S87S94.

11 Liu WJ, Hooi LS: Patients with end stage renal disease: a registry at Sultanah Aminah Hospital, Johor Bahru, Malaysia. Med J Malaysia 2007;62:197-200.

- 12 Hada R, Khakurel S, Agrawal RK, Kafle RK, Bajracharya SB, Raut KB: Incidence of end stage renal disease on renal replacement therapy in Nepal. Kathmandu Univ Med J 2009;7:301-305.

13 Ayodele OE, Alebiosu CO: Burden of chronic kidney disease: an international perspective. Adv Chronic Kidney Dis 2010;17:215224
14 Abraham G, Jayaseelan T, Matthew M, Padma P, Saravanan AK, Lesley N, Reddy YN, Saravanan S, Reddy YN: Resource settings have a major influence on the outcome of maintenance hemodialysis patients in South India. Hemodial Int 2010;14:211-217.

15 Ulasi II, Ijoma CK: The enormity of chronic kidney disease in Nigeria: the situation in a teaching hospital in South-East Nigeria. J Trop Med 2010;2010:501957.

16 Jha V: End-stage renal care in developing countries: the India experience. Ren Fail 2004;26:201-208.

17 Badmus TA, Arogundade FA, Sanusi AA, Akinsola WA, Adesunkanmi AR, Agbakwuru AO, Salako AB, Faponle AF, Oyebamiji EO, Adetiloye VA, Famurewa OC, Oladimeji BY, Fatoye FO: Kidney transplantation in a developing economy: challenges and initial report of three cases at Ile Ife. Cent Afr J Med 2005;51:102-106.

18 Farrington K, Hodsman A, Casula A, Ansell D, Feehally J: UK Renal Registry 11th annual report (December 2008). 4. ESRD prevalent rates in 2007 in the UK: national and centrespecific analyses. Nephron Clin Pract 2009; 111(suppl 1):c43-c68.

19 US Renal Data System: USRDS 2010 annual data report: atlas of chronic kidney disease and end-stage renal disease in the United States. Bethesda, National Institutes of Health, National Institute of Diabetes and Digestive and Kidney Diseases, 2010. http:// www.usrds.org/2010/ADR_booklet_2010 lowres.pdf,http://www.usrds.org/2009/pdf/ V2_02_INC_PREV_09.PDF (accessed December 20, 2010).

20 Hsu CY, McCulloch CE, Fan D, Ordoñez JD, Chertow GM, Go AS: Community-based incidence of acute renal failure. Kidney Int 2007;72:208-212.

21 Eachempati SR, Wang JC, Hydo LJ, Shou J, Barie PS: Acute renal failure in critically ill surgical patients: persistent lethality despite new modes of renal replacement therapy. J Trauma 2007;63:987-993.

22 Centers for Disease Control and Prevention (CDC): Prevalence of chronic kidney disease and associated risk factors - United States, 1999-2004. MMWR Morb Mortal Wkly Rep 2007;56:161-165.

23 Naicker S: End-stage renal disease in sub-Saharan Africa. Ethn Dis 2009;19(suppl 1):1315.

-24 Akinsola W, Odesanmi WO, Ogunniyi JO, Ladipo GO, Akinsola W, Odesanmi WO, Ogunniyi JO, Ladipo GO: Diseases causing chronic renal failure in Nigerians - a prospective study of 100 cases. Afr J Med Med Sci 1989;18:131-137.

25 Adetuyibi A, Akisanya JB, Onadeko BO: Analysis of the causes of death on the medical wards of the University College Hospital, Ibadan, over a 14-year period (1960-1973). Trans R Soc Trop Med Hyg 1976;70:466-473.
26 Mircescu G, Capsa D, Covic M, Caprioara MG, Gluhovschi G, Golea O, Ursea N, Gârneata L, Cepoi V, Constantinovici N, Covic A: Nephrology and renal replacement therapy in Romania - transition still continues (Cinderella story revisited). Nephrol Dial Transplant 2004;19:2971-2980.

27 Nelson CR, Knapp DA: Trends in antihypertensive drug therapy of ambulatory patients by US office-based physicians. Hypertension 2000;36:600-603.

28 Stafford RS, Monti V, Furberg CD, Ma J: Long-term and short-term changes in antihypertensive prescribing by office-based physicians in the United States. Hypertension 2006:48:213-218.

29 Ma J, Lee KV, Stafford RS: Changes in antihypertensive prescribing during US outpatient visits for uncomplicated hypertension between 1993 and 2004. Hypertension 2006; 48:846-852.

$30 \mathrm{Al}$ Khaja KA, Sequeira RP: Pharmacoepidemiology of antihypertensive drugs in primary care setting of Bahrain between 1998 and 2000. Pharmacoepidemiol Drug Saf 2006; 15: 741-748.

-31 McAlister FA, Campbell NR, Duong-Hua M, Chen Z, Tu K: Antihypertensive medication prescribing in 27,822 elderly Canadians with diabetes over the past decade. Diabetes Care 2006;29:836-841.

32 Kim KI, Kim Y, Kim HJ, Kang DH, Park JB, Choi DJ, Kim CH, KEY Study Group: Current status and characteristics of hypertension treatment by primary physicians in Korea: data from Korean epidemiology study on hypertension (KEY study). Am J Hypertens 2008:21:884-889.

33 Pillay T, Smith AJ, Hill SR: A comparison of two methods for measuring anti-hypertensive drug use: concordance of use with South African standard treatment guidelines. Bull World Health Organ 2009;87:466-471.

34 Ejeschke E, Ostermann T, Vollmar HC, Kröz M, Bockelbrink A, Witt CM, Willich SN, Matthes $\mathrm{H}$ : Valuation of prescribing patterns in a German network of CAM physicians for the treatment of patients with hypertension: a prospective observational study. BMC Fam Pract 2009;10:78.

- 35 Olanrewaju TO, Aderibigbe A, Busari OA, Sanya EO: Antihypertensive drug utilization and conformity to guidelines in a sub-Saharan African hypertensive population. Int J Clin Pharmacol Ther 2010;48:68-75.

-36 Feldstein CA, Garrido D, Chavin JM, Liendo $\mathrm{XM}$, de los Santos AR: Primary care survey of awareness and control of hypertension: a hospital-based study. Am J Ther 2010;17: 295-300.

37 Comper WD, Hilliard LM, Nikolic-Paterson DJ, Russo LM: Disease-dependent mechanisms of albuminuria. Am J Physiol Renal Physiol 2008;295:F1589-F1600. 
38 Russo LM, Sandoval RM, Campos SB, Molitoris BA, Comper WD, Brown D: Impaired tubular uptake explains albuminuria in early diabetic nephropathy. J Am Soc Nephrol 2009;20:489-494.

- 39 Freedman BI, Hicks PJ, Bostrom MA, Comeau ME, Divers J, Bleyer AJ, Kopp JB, Winkler CA, Nelson GW, Langefeld CD, Bowden DW: Non-muscle myosin heavy chain 9 gene MYH9 associations in African Americans with clinically diagnosed type 2 diabetes mellitus-associated ESRD. Nephrol Dial Transplant 2009;24:3366-3371.

-40 Leak TS, Mychaleckyj JC, Smith SG, Keene KL, Gordon CJ, Hicks PJ, Freedman BI, Bowden DW, Sale MM: Evaluation of a SNP map of 6q24-27 confirms diabetic nephropathy loci and identifies novel associations in type 2 diabetes patients with nephropathy from an African-American population. Hum Genet 2008;124:63-71.

-41 Forbes JM, Coughlan MT, Cooper ME: Oxidative stress as a major culprit in kidney disease in diabetes. Diabetes 2008;57:14461454.

42 Singh DK, Winocour P, Farrington K: Mechanisms of disease: the hypoxic tubular hypothesis of diabetic nephropathy. Nat Clin Pract Nephrol 2008;4:216-226.

43 Goh SY, Cooper ME: Clinical review: the role of advanced glycation end products in progression and complications of diabetes. J Clin Endocrinol Metab 2008;93:1143-1152.

-44 Flyvbjerg A, Denner L, Schrijvers BF, Tilton RG, Mogensen TH, Paludan SR, Rasch R: Long-term renal effects of a neutralizing RAGE antibody in obese type 2 diabetic mice. Diabetes 2004;53:166-172.

-45 Park S, Bivona BJ, Kobori H, Seth DM, Chappell MC, Lazartigues E, Harrison-Bernard LM: Major role for ACE-independent intrarenal ANG II formation in type II diabetes. Am J Physiol Renal Physiol 2010;298:F37F48.

-46 Matavelli LC, Huang J, Siragy HM: (Pro)renin receptor contributes to diabetic nephropathy by enhancing renal inflammation. Clin Exp Pharmacol Physiol 2010;37: 277-282.

47 Sasaki H, Kamijo-Ikemori A, Sugaya T, Yamashita K, Yokoyama T, Koike J, Sato T, Yasuda T, Kimura K: Urinary fatty acids and liver-type fatty acid binding protein in diabetic nephropathy. Nephron Clin Pract 2009;112:c148-c156.

-48 Lennon R, Pons D, Sabin MA, Wei C, Shield JP, Coward RJ, Tavare JM, Mathieson PW, Saleem MA, Welsh GI: Saturated fatty acids induce insulin resistance in human podocytes: implications for diabetic nephropathy. Nephrol Dial Transplant 2009;24:3288-3296.

-49 An WS, Kim HJ, Cho KH, Vaziri ND: Omega-3 fatty acid supplementation attenuates oxidative stress, inflammation, and tubulointerstitial fibrosis in the remnant kidney. Am J Physiol Renal Physiol 2009;297:F895F903.
50 Yilmaz MI, Saglam M, Qureshi AR, Carrero JJ, Caglar K, Eyileten T, Sonmez A, Cakir E, Oguz Y, Vural A, Yenicesu M, Stenvinkel P, Lindholm B, Axelsson J: Endothelial dysfunction in type-2 diabetics with early diabetic nephropathy is associated with low circulating adiponectin. Nephrol Dial Transplant 2008;23:1621-1627.

51 Yamaguchi Y, Iwano M, Suzuki D, Nakatani K, Kimura K, Harada K, Kubo A, Akai Y, Toyoda M, Kanauchi M, Neilson EG, Saito Y: Epithelial-mesenchymal transition as a potential explanation for podocyte depletion in diabetic nephropathy. Am J Kidney Dis 2009;54:653-664.

52 Yokoi H, Mukoyama M, Mori K, Kasahara M, Suganami T, Sawai K, Yoshioka T, Saito Y, Ogawa Y, Kuwabara T, Sugawara A, Nakao $\mathrm{K}$ : Overexpression of connective tissue growth factor in podocytes worsens diabetic nephropathy in mice. Kidney Int 2008;73: 446-455.

53 Jaffa AA, Usinger WR, McHenry MB, Jaffa MA, Lipstiz SR, Lackland D, Lopes-Virella M, Luttrell LM, Wilson PW: Connective tissue growth factor and susceptibility to renal and vascular disease risk in type 1 diabetes. J Clin Endocrinol Metab 2008;93:1893-1900.

54 Breyer JA: Diabetic nephropathy in insulindependent patients. Am J Kidney Dis 1992; 20:533-547.

55 Onuigbo MAC: Reno-prevention vs renoprotection: a critical re-appraisal of the evidence-base from the large RAAS blockade trials after ONTARGET - a call for more circumspection. QJM 2009;102:155-167.

56 Onuigbo MA: Is renoprotection with RAAS blockade a failed paradigm? Have we learnt any lessons so far? Int J Clin Pract 2010;64: 1341-1346.

57 Tsalamandris C, Allen TJ, Gilbert RE, et al: Progressive decline in renal function in diabetic patients with and without albuminuria. Diabetes 1994;43:649-655.

58 Keith DS, Nichols GA, Gullion CM, Brown JB, Smith DH: Longitudinal follow-up and outcomes among a population with chronic kidney disease in a large managed care organization. Arch Intern Med 2004;164:659663.

59 Menon V, Wang X, Sarnak MJ, et al: Longterm outcomes in nondiabetic chronic kidney disease. Kidney Int 2008;73:1310-1315.

60 Onuigbo MA: The natural history of chronic kidney disease revisited - a 72-month Mayo Health System Hypertension Clinic practice-based research network prospective report on end-stage renal disease and death rates in 100 high-risk chronic kidney disease patients: a call for circumspection. Adv Perit Dial 2009;25:85-88.

61 Bansal N, Hsu CY: Long-term outcomes of patients with chronic kidney disease. Nat Clin Pract Nephrol 2008;4:532-533.

62 Onuigbo MA: Causes of renal failure in patients with type 2 diabetes mellitus. JAMA 2003;290:1855, author reply 1855-1856.
63 Effects of ramipril on cardiovascular and microvascular outcomes in people with diabetes mellitus: results of the HOPE study and MICRO-HOPE substudy. Heart Outcomes Prevention Evaluation Study Investigators. Lancet 2000;355:253-259 (erratum published in Lancet 2000;356:860).

-64 Brenner BM, Cooper ME, de Zeeuw D, et al: Effects of losartan on renal and cardiovascular outcomes in patients with type 2 diabetes and nephropathy. N Engl J Med 2001;345:861-869.

- 65 Parving HH, Lehnert H, Brochner-Mortensen J, Gomis R, Andersen S, Arner P: The effect of irbesartan on the development of diabetic nephropathy in patients with type 2 diabetes. N Engl J Med 2001;345:870-878.

66 Onuigbo M, Weir MR: Evidence-based treatment of hypertension in patients with diabetes mellitus. Diabetes Obes Metab 2003;5:13-26.

-67 Lewis EJ, Hunsicker LG, Bain RP, Rohde $\mathrm{RD}$ : The effect of angiotensin-convertingenzyme inhibition on diabetic nephropathy. The Collaborative Study Group. N Engl J Med 1993;329:1456-1462 (erratum published in N Engl J Med 1993;330:152)

68 Ruggenenti P, Perna A, Gherardi G, et al: Renoprotective properties of ACE-inhibition in non-diabetic nephropathies with non-nephrotic proteinuria. Lancet 1999;354: 359-364.

-69 Lewis EJ, Hunsicker LG, Clarke WR, et al: Renoprotective effect of the angiotensin-receptor antagonist irbesartan in patients with nephropathy due to type 2 diabetes. $\mathrm{N} \mathrm{Engl} \mathrm{J}$ Med 2001;345:851-860.

70 Onuigbo MA, Onuigbo NT: Late onset renal failure from angiotensin blockade (LORFFAB): a prospective thirty-month Mayo Health System clinic experience. Med Sci Monit 2005;11:CR462-CR469.

71 Onuigbo MA, Onuigbo NT: Late-onset renal failure from RAAS blockade. Kidney Int 2006;70:1378-1379.

72 Onuigbo MA, Onuigbo NT: Late-onset renal failure from angiotensin blockade (LORFFAB) in $100 \mathrm{CKD}$ patients. Int Urol Nephrol 2008; 40:233-239.

-73 Onuigbo MA, Onuigbo NT: Does renin-angiotensin aldosterone system blockade exacerbate contrast-induced nephropathy in patients with chronic kidney disease? A prospective 50-month Mayo Clinic study. Ren Fail 2008;30:67-72.

74 ONTARGET Investigators, Yusuf S, Teo KK, Pogue J, Dyal L, Copland I, Schumacher H, Dagenais G, Sleight P, Anderson C: Telmisartan, ramipril, or both in patients at high risk for vascular events. N Engl J Med 2008; 358:1547-1559.

75 Onuigbo MA, Onuigbo NT: Worsening renal failure in older chronic kidney disease patients with renal artery stenosis concurrently on renin angiotensin aldosterone system blockade: a prospective 50 -month Mayo-Health-System clinic analysis. QJM 2008;101:519-527. 
76 Onuigbo MA, Onuigbo NT: Renal failure and concurrent RAAS blockade in older CKD patients with renal artery stenosis: an extended Mayo Clinic prospective 63-month experience. Ren Fail 2008;30:363-371.

77 Onuigbo MAC: An analytical review of the evidence-base for reno-protection from the large RAAS blockade trials after ONTARGET. Re-visitation of the potential for iatrogenic renal failure with RAAS blockade? A call for caution. Nephron Clin Pract 2009; 113:c63-c69.

78 Suissa S, Hutchinson T, Brophy JM, Kezouh A: ACE-inhibitor use and the long-term risk of renal failure in diabetes. Kidney Int 2006; 69:913-919.

79 Kunz R, Friedrich C, Wolbers M, Mann JF: Meta-analysis: effect of monotherapy and combination therapy with inhibitors of the renin angiotensin system on proteinuria in renal disease. Ann Intern Med 2008; 148:3048.

80 Thuraisingham RC, Yaqoob MM: Blood pressure guidelines in chronic kidney disease: a critical review. Nephron Clin Pract 2009;113:c294-c300.

-81 Mogensen CE, Neldam S, Tikkanen I, et al: Randomised controlled trial of dual blockade of renin-angiotensin system in patients with hypertension, microalbuminuria, and non-insulin dependent diabetes: the Candesartan and Lisinopril Microalbuminuria (CALM) study. BMJ 2000;321:1440-1444.

-82 Svensson P, de Faire U, Sleight P, Yusuf S, Ostergren J: Comparative effects of ramipril on ambulatory and office blood pressures. A HOPE substudy. Hypertension 2001;38:e28e32.

-83 Riley RD, Lambert PC, Staessen JA, et al: Meta-analysis of continuous outcomes combining individual patient data and aggregate data. Statist Med 2008;27;1870-1893.

-84 Ameringer S, Serlin RC, Ward S: Simpson's paradox and experimental research. Nurs Res 2009;58:123-127.

85 Cooper H, Patall EA: The relative benefits of meta-analysis conducted with individual participant data versus aggregated data. Psychol Methods 2009; 14:165-176.

86 Mann JF, Schmieder RE, McQueen M, et al, ONTARGET investigators: Renal outcomes with telmisartan, ramipril, or both, in people at high vascular risk (the ONTARGET study): a multicentre, randomised, doubleblind, controlled trial. Lancet 2008;372:547553.

87 Ballermann BJ, Onuigbo MAC: Angiotensins; in Fray JCS (ed): Handbook of Physiology; section 7: The endocrine system, vol III: Endocrine regulation of water and electrolyte balance. New York, Oxford University Press, pp 104-155.

88 Zhang SL, Guo J, Moini B, Ingelfinger JR: Angiotensin II stimulates Pax-2 in rat kidney proximal tubular cells: impact on proliferation and apoptosis. Kidney Int 2004;66: 2181-2192.
89 Chen CO, Park MH, Forbes MS, et al: Angiotensin converting enzyme inhibition aggravates renal interstitial injury resulting from partial unilateral ureteral obstruction in the neonatal rat. Am J Physiol Renal Physiol 2007;292:F946-F955.

90 Rossing K, Jacobsen P, Pietraszek L, Parving $\mathrm{HH}$ : Renoprotective effects of adding angiotensin II receptor blocker to maximal recommended doses of ACE inhibitor in diabetic nephropathy: a randomized double-blind crossover trial. Diabetes Care 2003;26:2268-2274.

-91 ONTARGET Investigators, Yusuf S, Teo KK, Pogue J, et al: Telmisartan, ramipril, or both in patients at high risk for vascular events. N Engl J Med 2008;358:1547-1559.

$\$ 2$ Onuigbo MA, Onuigbo NT: Use of ultrahigh RAAS blockade: implications for exacerbation of renal failure. Kidney Int 2006; 69:194-195.

-93 Servilla KS, Singh AK, Hunt WC, Harford AM, Miskulin D, Meyer KB, Bedrick EJ, Rohrscheib MR, Tzamaloukas AH, Johnson HK, Zager PG: Anemia management and association of race with mortality and hospitalization in a large not-for-profit dialysis organization. Am J Kidney Dis 2009; 54:498-510.

94 Winkelmayer WC, Liu J, Brookhart MA: Altitude and all-cause mortality in incident dialysis patients. JAMA 2009;301:508-512.

$\$ 95$ Onuigbo MA: Does concurrent renin-angiotensin-aldosterone blockade in (older) chronic kidney disease patients play a role in the acute renal failure epidemic in US hospitalized patients? Three cases of severe acute renal failure encountered in a northwestern Wisconsin Nephrology practice. Hemodial Int 2009;13(suppl 1):S24-S29.

96 Onuigbo MA: Radiographic contrast-induced nephropathy and patient mortality. Mayo Clin Proc 2008;83:1412-1413.

97 Ahmed AK, Kamath NS, El Kossi M, et al: The impact of stopping inhibitors of the renin-angiotensin system in patients with advanced chronic kidney disease. Nephrol Dial Transplant 2009. DOI: $10.1093 /$ ndt/ gfp511.

$\$ 98$ Onuigbo MA: The impact of stopping inhibitors of the renin-angiotensin system in patients with advanced chronic kidney disease. Nephrol Dial Transplant. 2010;25: 1344-1345.

99 Granger CB, McMurray JJ, Yusuf S, et al: Effects of candesartan in patients with chronic heart failure and reduced left-ventricular systolic function intolerant to angiotensin-converting-enzyme inhibitors: the CHARM-Alternative trial. Lancet 2003;362(9386):772-776.

100 Pfeffer MA, Swedberg K, Granger CB, et al: Effects of candesartan on mortality and morbidity in patients with chronic heart failure: the CHARM-overall programme. Lancet 2003;362:759-766.
101 Rahman M, Pressel S, Davis BR, et al: Renal outcomes in high-risk hypertensive patients treated with an angiotensin-converting enzyme inhibitor or a calcium channel blocker vs a diuretic: a report from the Antihypertensive and Lipid-Lowering Treatment to Prevent Heart Attack Trial (ALLHAT). Arch Intern Med 2005;165:936-946.

102 Onuigbo MA: ALLHAT findings revisited in the context of subsequent analyses, other trials, and meta-analyses. Arch Intern Med 2009; 169:1810.

103 Al-Azzam SI, Al-Husein BA, Abu-Dahoud EY, Dawoud TH, Al-Momany EM: Etiologies of acute renal failure in a sample of hospitalized Jordanian patients. Ren Fail 2008; 30:373-376.

104 Louis BM, Hoch BS, Hernandez C, et al: Protection from the nephrotoxicity of contrast dye. Renal Fail 1996;18:639-646.

105 Kini AS, Mitre CA, Kamran M, et al: Changing trends in incidence and predictors of radiographic contrast nephropathy after percutaneous coronary intervention with use of fenoldopam. Am J Cardiol 2002; 89:999-1002.

106 Toprak O, Cirit M, Bayata S, Yesil M, Aslan SL: The effect of pre-procedural captopril on contrast-induced nephropathy in patients who underwent coronary angiography. Anadolu Kardiyol Derg 2003;3:98103.

107 Cirit M, Toprak O, Yesil M, et al: Angiotensin-converting enzyme inhibitors as a risk factor for contrast-induced nephropathy. Nephron Clin Pract 2006;104:c20-c27.

108 Komenda P, Zalunardo N, Burnett S, et al: Conservative outpatient renoprotective protocol in patients with low GFR undergoing contrast angiography: a case series. Clin Exp Nephrol 2007;11:209-213.

109 Gupta RK, Kapoor A, Tewari S, et al: Captopril for prevention of contrast-induced nephropathy in diabetic patients; a randomized study. Indian Heart J 1995;51:521526.

110 Dangas G, Iakovou I, Nikolsky E, et al: Contrast-induced nephropathy after percutaneous coronary interventions in relation to chronic kidney disease and hemodynamic variables. Am J Cardiol 2005;95:13-19.

111 Kiski D, Stepper W, Brand E, Breithardt G, Reinecke H: Impact of renin-angiotensinaldosterone blockade by angiotensin-converting enzyme inhibitors or AT-1 blockers on frequency of contrast medium-induced nephropathy: a post-hoc analysis from the Dialysis-versus-Diuresis (DVD) trial. Nephrol Dial Transplant 2010;25:759-764.

112 Rosenstock JL, Bruno R, Kim JK, Lubarsky L, Schaller R, Panagopoulos G, De Vita MV, Michelis MF: The effect of withdrawal of ACE inhibitors or angiotensin receptor blockers prior to coronary angiography on the incidence of contrast-induced nephropathy. Int Urol Nephrol 2008;40:749-755. 
-113 Richer C, Giroux B, Plouin PF, Maarek B, Giudicelli JF: Captopril: pharmacokinetics, antihypertensive and biological effects in hypertensive patients. Br J Clin Pharmacol 1984; 17:243-250.

-114 Giudicelli JF, Chaignon M, Richer C, Giroux B, Guedon J: Influence of chronic renal failure on captopril pharmacokinetics and clinical and biological effects in hypertensive patients. Br J Clin Pharmacol 1984;18:749-758.

-115 Thakar CV, Kharat V, Blanck S, Leonard AC: Acute kidney injury after gastric bypass surgery. Clin J Am Soc Nephrol 2007; 2:426-430.

-116 Khurana A, McLean L, Atkinson S, Foulks CJ: The effect of oral sodium phosphate drug products on renal function in adults undergoing bowel endoscopy. Arch Intern Med 2008;168:593-597.

-117 Russmann S, Lamerato L, Marfatia A, et al: Risk of impaired renal function after colonoscopy: a cohort study in patients receiving either oral sodium phosphate or polyethylene glycol. Am J Gastroenterol 2007; 102:2655-2663.

-118 Arora P, Rajagopalam S, Ranjan R, et al: Preoperative use of angiotensin-converting enzyme inhibitors/angiotensin receptor blockers is associated with increased risk for acute kidney injury after cardiovascular surgery. Clin J Am Soc Nephrol 2008;3: 1266-1273.

119 Markowitz GS, Nasr SH, Klein P, et al: Renal failure due to acute nephrocalcinosis following oral sodium phosphate bowel cleansing. Hum Pathol 2004;35:675-684.

-120 Rose M, Karlstadt RG, Walker K: Renal failure following bowel cleansing with a sodium phosphate purgative. Nephrol Dial Transplant 2005;20:1518-1519.
121 Russmann S, Lamerato L, Marfatia A, et al: Risk of impaired renal function after colonoscopy: a cohort study in patients receiving either oral sodium phosphate or polyethylene glycol. Am J Gastroenterol 2007; 102:2655-2663.

122 Khurana A, McLean L, Atkinson S, Foulks CJ: The effect of oral sodium phosphate drug products on renal function in adults undergoing bowel endoscopy. Arch Intern Med 2008;168:593-597.

123 Silas Jh, Klenka Z, Solomon SA: Captopril induced reversible renal failure: a marker of renal artery stenosis affecting a solitary kidney. Br Med J (Clin Res Ed) 1983;286: 1702-1703.

124 Murphy BF, Whitworth JA, Kincaid-Smith P: Renal insufficiency with combinations of angiotensin converting enzyme inhibitors and diuretics. Br Med J (Clin Res Ed) 1984; 288:844-845.

125 Jackson B, McGrath BP, Matthews PG, Wong C, Johnston C: Differential renal function during angiotensin converting enzyme inhibition in renovascular hypertension. Hypertension 1986;8:650-654.

-126 Kalra PA, Mamtora H, Holmes AM, Waldek $S$ : Renovascular disease and renal complications of angiotensin-converting enzyme inhibitor therapy. Q J Med 1990;77:10131018.

-127 Devoy MAB, Tomson CR, Edmunds ME, Feehally J, Walls J: Deterioration in renal function associated with angiotensin converting enzyme inhibitor therapy is not always reversible. J Intern Med 1992;232: 493-498.

128 Raine AE: Angiotensin-converting enzyme inhibition and renovascular disease. Q J Med 1990;77:997-999.

129 Thomas MC: Diuretics, ACE inhibitors and NSAIDs - the triple whammy. Med J Aust 2000;172:184-185.

130 Boyd IW, Mathew TH, Thomas MC: Cox-2 inhibitors and renal failure: the triple whammy revisited. Med J Aust 2000;173: 274.
131 Descombes E, Fellay G: End-stage renal failure after irbesartan prescription in a diabetic patient with previously stable chronic renal insufficiency. Ren Fail 2000;22: $815-821$.

132 Thomas MC: Diuretics, ACE inhibitors and NSAIDs - the triple whammy. Med J Aust 2000;172:184-185.

133 Loboz KK, Shenfield GM: Drug combinations and impaired renal function - the "triple whammy'. Br J Clin Pharmacol 2005;59: 239-243.

134 Raine AE: Angiotensin-converting enzyme inhibition and renovascular disease. Q J Med 1990;77:997-999.

135 Jafar TH, Schmid CH, Landa M, et al, ACE Inhibition in Progressive Renal Disease Study Group: Angiotensin-converting enzyme inhibitors and progression of nondiabetic renal disease. A meta-analysis of patient-level data. Ann Intern Med 2001;135; 73-87.

136 Jafar TH, Stark PC, Schmid CH, et al, ACE Inhibition in Progressive Renal Disease Study Group: Progression of chronic kidney disease: the role of blood pressure control, proteinuria, and angiotensin-converting enzyme inhibition - a patient-level meta-analysis. Ann Intern Med 2003;139; 244-252.

137 Kent DM, Jafar TH, Hayward RA, et al, ACE Inhibition in Progressive Renal Disease Study Group: Progression risk, urinary protein excretion, and treatment effects of angiotensin-converting enzyme inhibitors in nondiabetic kidney disease. J Am Soc Nephrol 2007;18:1959-1965.

138 Onuigbo MA: Syndrome of rapid-onset end-stage renal disease: a new unrecognized pattern of CKD progression to ESRD. Ren Fail 2010;32:954-958.

139 Go AS, Parikh CR, Ikizler TA, Coca S, Siew ED, Chinchilli VM, et al: The Assessment, Serial Evaluation, and Subsequent Sequelae of Acute Kidney Injury (ASSESS-AKI) study: design and methods. BMC Nephrol 2010;11:22. 